\title{
De Novo Three-Way Chromosome Translocation [46,XX,t(1;20;4) (p32;q12;q32)] in a Patient with Developmental Delay: A Case Report
}

\author{
Gelişme Geriliği Olan Bir Hastada Yeni Oluşum Üçlü Kromozom \\ Translokasyonu [46,XX,t(1;20;4)(p32;q12;q32)]: Bir Olgu Sunumu
}

Ali KARAMAN', Tülay TOS²

${ }^{1}$ Erzurum Nenehatun Obstetrics and Gynecology Hospital, Department of Medical Genetics, Erzurum, Turkey

${ }^{2}$ Dr. Sami Ulus Children's Health and Diseases Training and Research Hospital, Department of Medical Genetics, Ankara, Turkey

\begin{abstract}
Complex chromosome rearrangements (CCRs) involve more than two breakpoints on two or more chromosomes are uncommon occurrences. We report a female with developmental delay with a complex three-way balanced translocation $[46, X X, t(1 ; 4 ; 20)(p 32 ; q 32 ; q 12)]$ identified by karyotyping. This paper is the first report of reciprocal translocation involving $1 p, 4 q$ and $20 q$ associated with the developmental delay. The developmental delay may be due to the rearrangement of genetic material at these breakpoints and this incident may cause developmental delay.
\end{abstract}

Key Words: Chromosomal translocation, Developmental delay

\section{ÖZET}

Kompleks kromozom düzenlenmeleri iki ya da daha çok kromozomda ikiden fazla kırıma noktasını içeren sık olmayan oluşumlardır. Biz karyotip analizi sonucunda kompleks bir üçlü dengeli translokasyonlu [46,XX,t(1;4;20)(p32;q32;q12)] gelişme geriliği olan bir kız çocuğu rapor ediyoruz. Bu yazı 1p, 4q ve $20 q$ içeren resiprokal translokasyon ile gelişme geriliğinin birlikte olduğu ilk rapordur. Sorun muhtemelen kritik bir ilişkiye sahip bu kırık noktalarında genetik materyalin yeniden düzenlenmesine bağlı olabilir ve bu olay gelişimsel gecikmeye neden olabilir.

Anahtar Sözcükler: Kromozomal translokasyon, Gelişme geriliği

\section{INTRODUCTION}

Reciprocal de novo translocations occur in about 1 in 2,000 newborns (1). Although balanced translocations are not often associated with abnormal phenotypes, unbalanced translocations resulting in deleted or altered gene sequences usually cause appreciable clinical features $(2,3)$. Unbalanced translocations even more unusual are complex chromosome rearrangements (CCRs). CCRs are structural abnormalities that involve more than two break points and exchange of genetic material between two or more chromosomes $(4,5)$. Almost all the carriers of the balanced reciprocal translocations are believed to be normal by phenotype. Moreover, it is known that the modification or inactivation of specific disease genes at chromosomal breakpoints have been very phenomenal in identifying genes that are associated with a variety of disorders, mostly early-onset disorders (6). The most common CCRs involve three chromosomes with breakpoints on each chromosome.
The occurrence of three-way multiple translocations is rare and often difficult to distinguish from balanced translocations without additional diagnostic tools such as fluorescence in situ hybridization (FISH) or microarray-based comparative genomic hybridization (array CGH) (7-9).

In the present paper, we report an 8-year-old female with developmental delay and myopathic face in whom we found a de novo complex translocation of 46,XX,t(1;4;20)(p32;q32;q12).

\section{CASE REPORT}

The proband is an 8-year-old female who was referred for developmental delay to our hospital. She was born at term by cesarean section to a 29-year-old mother. The proband's birth weight was 2200gr ( $<3 \mathrm{rd}$ percentile) and her length was $47 \mathrm{~cm}$ (10th-25th percentile). The mother reports that she did not drink alcohol, smoke cigarettes, or use any unusual medications 
during the pregnancy. The father of the proband was 33-yearold with no prior family history of congenital abnormalities. At examination of the patient, she was 8-year-old, her weight was $16.4 \mathrm{~kg}$ ( $<3$ th centile) and her height $112 \mathrm{~cm}(<3$ th centile). An Auditory Brainstem Response test revealed bilateral normal sensorineural hearing. Cranial magnetic resonance imaging (MRI) revealed no pathology. Upon physical examination, the patient displayed minor dysmorphic features including simple ear, myopathic face, and clinodactyly (Figure 1A-C). Informed consent was received from parents for photographs. No other remarkable dysmorphic features or abnormalities were noted. Conventional cytogenetic analysis was performed on stimulated 72-hour culture of a peripheral blood specimen. The cells were cultured and processed by conventional methods and the chromosomes were stained with Giemsa-TrypsinGiemsa banding (GTG). The karyotype was determined to be $46, X X, t(1 ; 4 ; 20)(p 32 ; q 32 ; q 12)$ (Figure 2). The parents had normal chromosomal structure. Similarly, the first female child showed normal 46,XX karyotype. The family history was unremarkable.
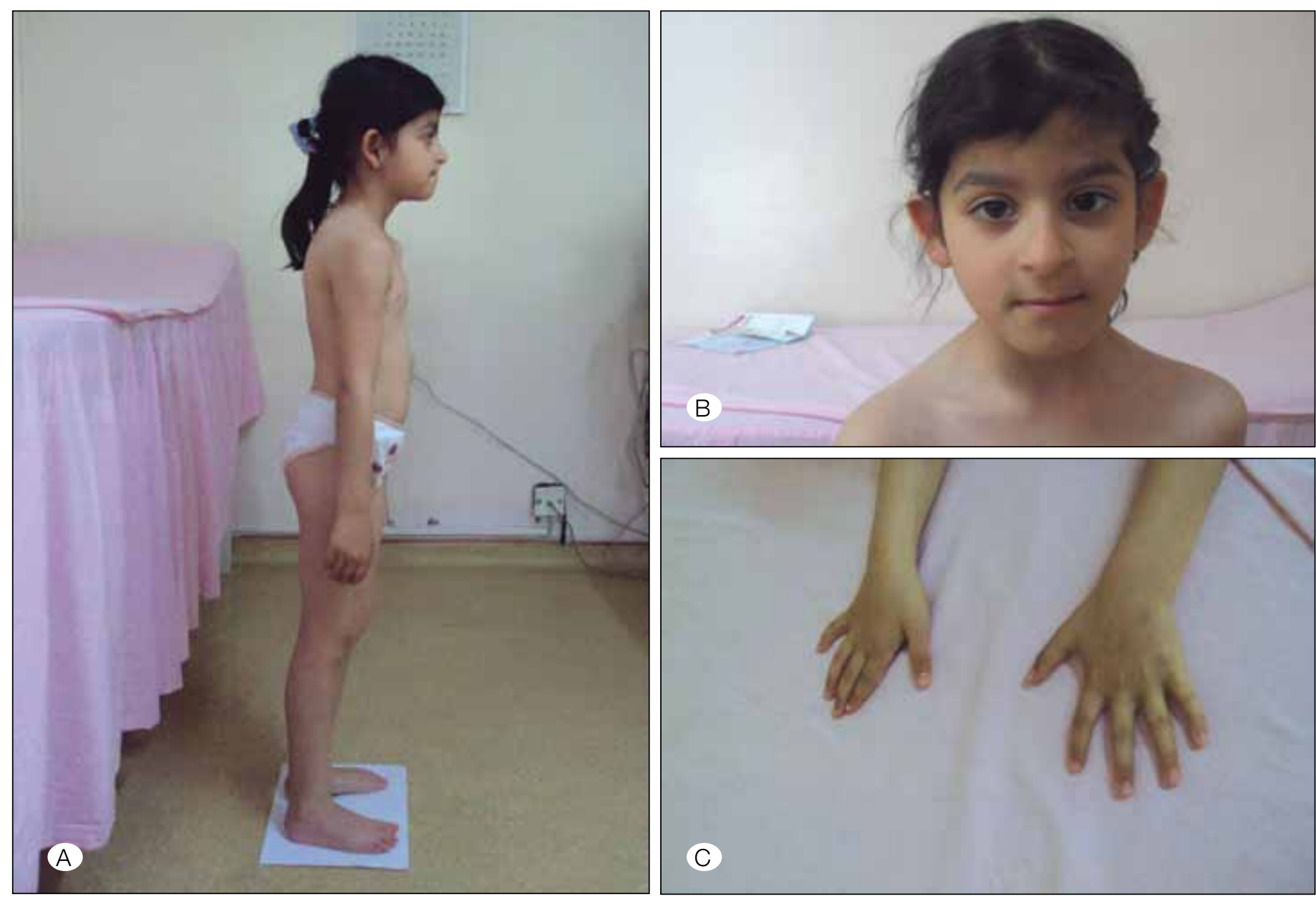

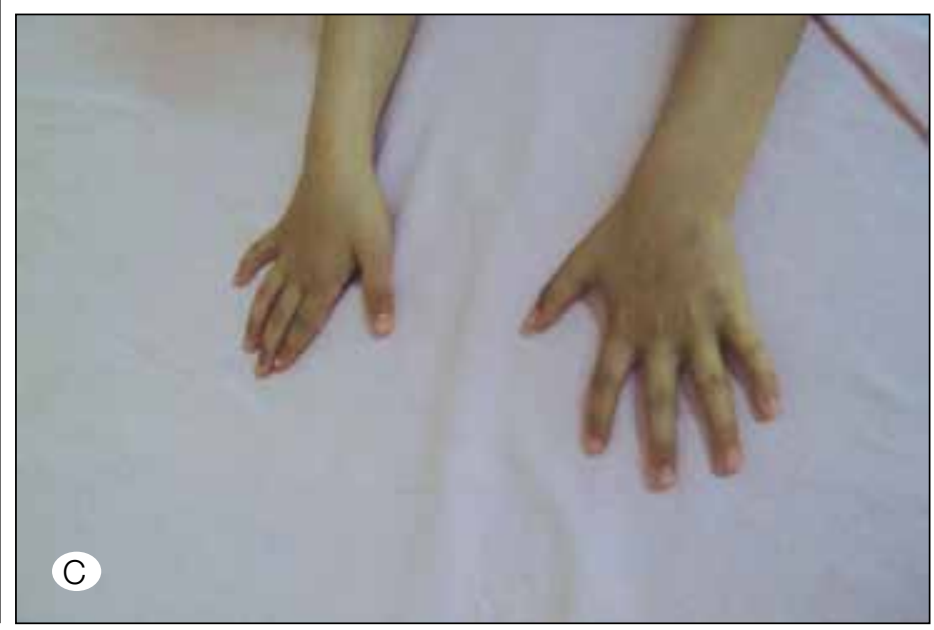

\section{DISCUSSION}

The common cause of mental retardation and the wide range of physical abnormalities is balanced chromosome rearrangement. As such, it is difficult to interpret, posing as a diagnostic chalange in human development. We report the cytogenetic finding of a patient with a complex chromosome rearrangement involving 1p32, 4q32 and $20 q 12$ showing an association with developmental delay, simple ears, and clinodactyly. This association has not been reported previously.

Failure to detect the correct chromosomal recipient would have resulted in false results of the prenatal diagnosis performed in the second and third pregnancy of the consultand. This finding stresses the importance of cryptic terminal translocations in clinical cytogenetics. Balanced chromosomal translocations may cause damage or alteration of the functional genes at the breakpoints of the defective chromosomes resulting in the disease phenotype (10). It was described previously that children who inherit reciprocal balanced translocation from one of the parents show association with congenital malformation $(11-13)$.

Figure 1: The appearance of the patient. 


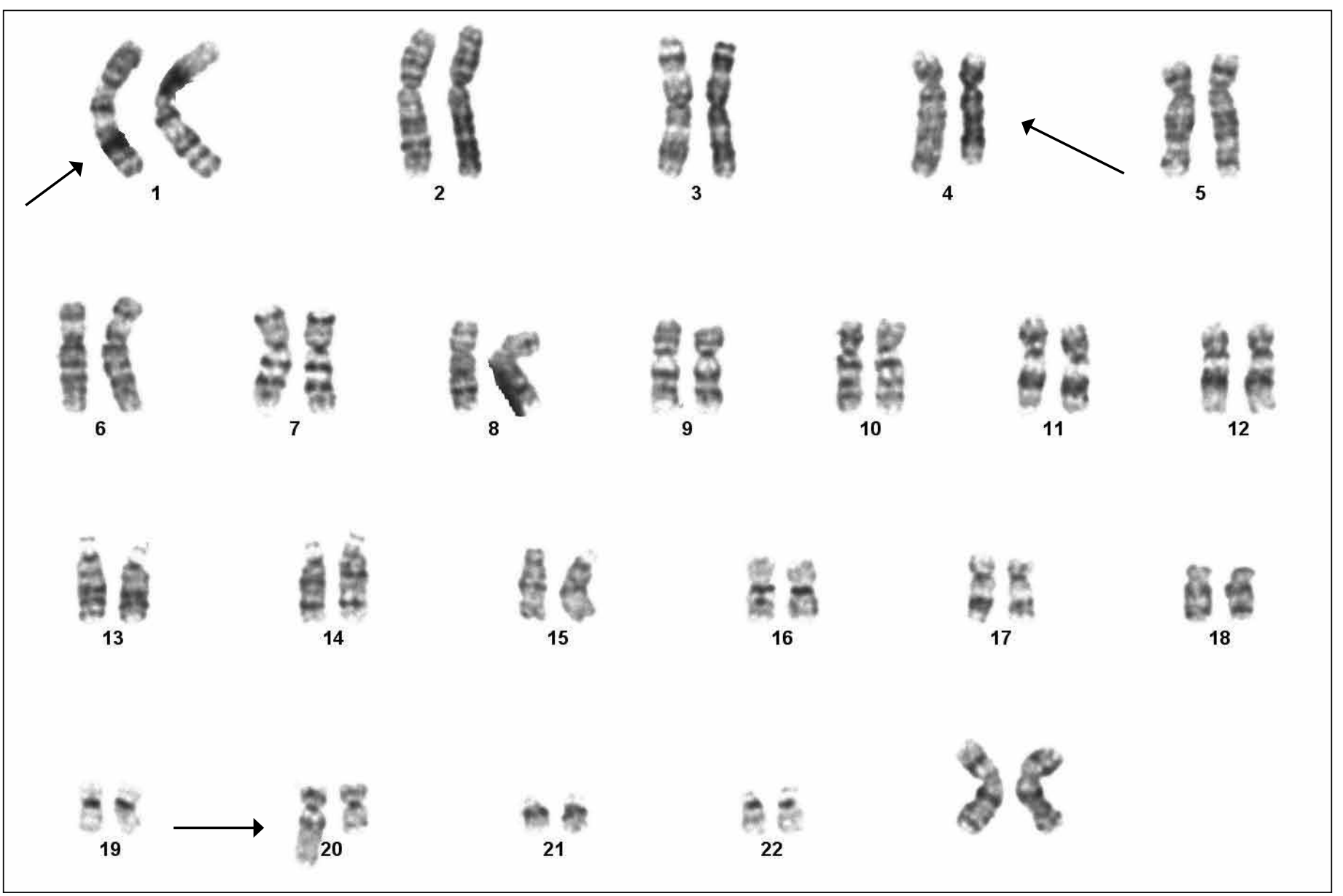

Figure 2: Karyotype of the patient. Short arrow shows the $\operatorname{der}(20)$. Long arrows indicate the breakpoints.

The risk for offspring of a carrier of a balanced CCR is difficult to estimate (14). Batista et al gave a risk of miscarriage of about $50 \%$ based on an extended review of 30 families with CCRs (15). Gorski et al. analysed 25 CCR families with 67 informative pregnancies and found a risk of abnormalities of $18.4 \%$ for live births (16). Nearly $50 \%$ of all liveborn offspring were also CCR carriers. The overall risk of an abnormal outcome of pregnancy seems to be about $50 \%$.

In carriers of balanced translocation, the possible reason for the association of congenital malformations could be gene inactivation or disruption at the breakpoint or a position effect (17). However, in the case of inherited reciprocal translocation seen in the proband, the breakpoint could inactive genes, subsequently unmasking a recessive allele inherited from the other parent (18). The other possible reason could be the occurrence of unequal crossing-over during meiosis that may have resulted in submicroscopic duplications or deletions, as proposed by Jacobs (17).

The deletion may be causing a position effecton the chromosome and may play a role in the proband's phenotype, either because the chromosomal rearrangement separated a promoter from its transcriptional regulatory element, resulting in gene silencing; the rearrangement juxtaposed a gene with an enhancer from another gene, leading to inappropriate gene expression; or the rearrangement moved a gene and its regulatory elements to a region of the genome that is transcriptionally silent, such as heterochromatin. Alternatively, the translocation breakpoints may have interrupted a gene or genes.

In view of an increased risk of having congenitally abnormal children, carriers of balanced reciprocal translocation should therefore be advised to seek genetic counseling. The genetic counseling for a balanced translocation carrier is often difficult and may require some caution, especially when the fetal karyotype is balanced.

\section{REFERENCES}

1. Warburton D. De novo balanced chromosome rearrangements and extra marker chromosomes identified at prenatal diagnosis: Clinical significance and distribution of breakpoints. Am J Hum Genet 1991;49:995-1013.

2. Kim HG, Herrick SR, Lemyre E, Kishikawa S, Salisz JA, Seminara $S$, et al. Hypogonadotropic hypogonadism and cleft lip and palate caused by a balanced translocation producing haploinsufficiency for FGFR1. J Med Genet 2005;42:666-72. 
3. Ligon AH, Moore SD, Parisi MA, Mealiffe ME, Harris DJ, Ferguson $\mathrm{HL}$, et al. Constitutional rearrangement of the architectural factor HMGA2: A novel human phenotype including overgrowth and lipomas. Am J Hum Genet 2005;76:340-8.

4. KleczkowskaA, Fryns JP, Berghe HVan den. Complex chromosomal rearrangements (CCR) and their genetic consequences. J Genet Hum 1982;30:199-214.

5. Berend SA, Bodamer OA, Shapira SK, Shaffer LG, Bacino CA. Familial complex chromosomal rearrangement resulting in a recombinant chromosome. Am J Med Genet 2002; 109:311-7.

6. Bugge $M$, Bruun-Petersen $G$, Brondum-Nielsen $K$, Friedrich $U$, Hansen J, Jensen $G$, et al. Disease associated balanced chromosome rearrangements: A resource for large-scale genotypephenotype delineation in man. J Med Genet 2000;37:858-65.

7. Spikes AS, Hegmann K, Smith JL, Shaffer LG. Use of fluorescence in situ hybridization to clarify a complex chromosomal rearrangement in a child with multiple congenital anomalies. Am J Med Genet 1995;57:31-4.

8. De Gregori M, Ciccone R, Magini P, Pramparo T, Gimelli S, Messa $J$, et al. Cryptic deletions are a common finding in "balanced" reciprocal and complex chromosome rearrangements: a study of 59 patients. J Med Genet 2007;44:750-62.

9. Gribble SM, Prigmore E, Burford DC, Porter KM, Ng BL, Douglas EJ, et al. The complex nature of constitutional de novo apparently balanced translocations in patients presenting with abnormal phenotypes. J Med Genet 2005;42:8-16.

10. Battaglia A, Hoyme HE, Dallapiccola B, Zackai E, Hudgins L, McDonald-McGinn D, et al. Further delineation of deletion 1p36 syndrome in 60 patients: A recognizable phenotype and common cause of developmental delay and mental retardation. Pediatrics 2008;121:404-10.
11. Kikuchi I, Nagamine M, Ueda A, Mihara K, Seita M, Minoda M. Chromosomal translocation $\mathrm{t}(13 ; 16)$ in a patient with idiopathic hypogonadotropic hypogonadism. Intern Med 1993;32:465-7.

12. Wenger SL, Steele MW, Boone LY, Lenkey SG, Cummins JH, Chen $X Q$. "Balanced" karyotypes in six abnormal offspring of balanced reciprocal translocation normal carrier parents. Am J Med Genet 1995;55:47-52.

13. Madan K, Nieuwint AW, van Bever Y. Recombination in a balanced complex translocation of a mother leading to a balanced reciprocal translocation in the child. Review of 60 cases of balanced complex translocation. Hum Genet 1997;99:806-15.

14. Flint J, Wilkie AO, Buckle VJ, Winter RM, Holland AJ, McDermid $\mathrm{HE}$. The detection of subtelomeric chromosomal rearrangements in idiopathic mental retardation. Nat Genet 1995;9:132-40.

15. Batista DAS, Pai S, Stetten G. Molecular analysis of a complex chromosomal rearrangement by in situ hybridization. Am J Med Genet 1994;53:255-63.

16. Gorski JL, Kistenmacher ML, Punnett HH, Zackai EH, Emanuel BS. Reproductive risks for carriers of complex chromosome rearrangements: Analysis of 25 families. Am $J$ Med Genet 1988,29:247-61.

17. Buhler EM. Unmasking of heterozygosity by inheriting balanced translocations. Implications for prenatal diagnosis and gene mapping. Ann Genet 1983;26:133-7.

18. Kolehmainen J, Wilkinson R, Lehesjoki AE, Chandler K, KivitieKallio S, Clayton-Smith J, et al. Delineation of Cohen syndrome following a large-scale genotype-phenotype screen. Am J Hum Genet 2004;75:122-7. 